\title{
DETOXIFICATION OF CASSAVA LEAVES
}

\author{
A.M.B. PRIYADARSHANI ${ }^{1}$, E.R. JANSZ ${ }^{* 1}$, H. PEIRIS ${ }^{1}$ \& S. JAYASINGHE ${ }^{2}$ \\ ${ }^{1}$ Department of Biochemistry, University of Sri Jayewardenepura. \\ ${ }^{2}$ Department of Medicine, University of Colombo.
}

(Received: 09 December 2002 ; accepted: 25 February 2003)

\begin{abstract}
Goitre has been observed in certain areas of the district of Monaragala, Sri Lanka, where cassava leaf is consumed daily. This study demonstrates that traditional methods of cooking cassava leaf result in considerable residual free cyanide. This would justify the conclusion that cassava leaf consumption causes goitre. Two methods have been worked out to reduce the free cyanide content to a non-detectable level $(<0.5 \mathrm{ppm})$ without reduction of protein content. Both methods depend on making use of the endogenous enzyme linamarase. A method using boiling water to set off the hydrolytic reaction is dependent on the fact that the linamarase content of the leaves that are used in cooking is of the order of $>1 \mathrm{mg} \mathrm{CN}^{-} \mathrm{mg}$ dry $\mathrm{wt}^{-1} \mathrm{~min}^{-1}$.
\end{abstract}

Keywords: Cassava, cyanide, detoxification, goitre, Manioc leaf

\section{INTRODUCTION}

Cassava, Manioc (Manihot esculenta Crantz) tuber is a well known starchy staple in Africa. ${ }^{1}$ Many toxic effects arising mainly from thiocyanate resulting from metabolism of cyanide have been reported. ${ }^{2}$ Thiocyanate which is produced by a detoxification mechanism leads to goitre. ${ }^{3}$ This has been well known for decades and is due to inhibition of $\mathrm{I}^{-}$uptake by the iodide pump of the thyroid gland by thiocyanate. ${ }^{3}$

There is no report in the literature for goitre being caused by consuming the leaf of cassava. This is probably due to the fact that the leaf is usually not consumed in quantity. A special situation exists in persistently drought stricken areas in Monaragala in the South East of Sri Lanka where a District Medical Officer of a small hospital in Badalkumbura in the Monaragala district noticed high prevalence of goitre and high consumption of cassava leaf (Dr. P.L. Attapattu, private communication).

This unusual situation had arisen due to a combination of drought, poverty and ignorance of the existence of cyanogenic glucosides in all parts of the cassava plant. The drought contributed to cassava being the most suitable plant to cultivate. The cassava tubers are sold and rice is purchased. Their meal thus comprises manioc leaf (35-100 $\left.\mathrm{g} \mathrm{day}^{-1}\right)$ and rice. Poverty restricts the choice of all fish, meat and most

\footnotetext{
- Corresponding author
} 
vegetables. ${ }^{4}$ The people of the area consume manioc leaf after cutting it into large pieces and mild heat treatment, for fear of loss of vitamins. The combination of circumstances has led to 73 cases of goitre being reported to the Base Hospital in Sirigala in Monaragala, which serves only a few thousand people. ${ }^{4}$ Cases were mostly females (63) of 35-45 years of age. Various degrees of goitre development were noticęd, but the rate of development of goitre was not clear.

The objectives of this study were to:

(I) Determine the total cyanide content of the correct maturity of leaves that are usually consumed.

(II) Determine residual free and bound cyanide after using traditional methods of cooking.

(III) Determine methods of cooking that would reduce the total cyanide to less than $0.5 \mathrm{ppm}$ (detoxification).

(Iv) Estimate linamarase activity in cassava leaf in order to provide the theoretical basis for the detoxification procedure.

\section{METHODS \& MATERIALS}

Cassava leaf: The $3^{\text {rd }}, 4^{\text {th }}$, and $5^{\text {th }}$ leaves that are normally eaten, were collected. Moisture content was determined by the Dean and Stark method ${ }^{5}$ and by drying in an oven at $105^{\circ} \mathrm{C}$ to constant weight. ${ }^{6}$

\section{Traditional Methods of Cooking:}

(a) "Malluma": Cassava leaves (5 g) were sliced and mixed (1:1) with grated coconut and then tempered for $5 \mathrm{~min}$ in a pan.

(b) Cassava leaves ( $5 \mathrm{~g}$ ) were sliced and fried in a small amount of coconut oil for 5 min.

The products in each case were used to determine the free and bound cyanide.

\section{Detoxification Methods:}

(a) Cassava leaves were sliced and pounded in a mortar. Thin slices were kept for $2 \mathrm{~h}$ at ambient temperature $\left(29-30^{\circ} \mathrm{C}\right)$ and analysed for free and bound cyanide.

(b) Boiling water was poured on to cassava leaf chopped into large pieces $\left(10 \mathrm{~cm}^{2}\right.$ leaf). This was left to stand for $2 \mathrm{~h}$ until cooking and then analysed for free and bound cyanide. All analyses were carried out in duplicate.

\section{Isolation of Linamarase:}

(a) For use in assays. Cassava rind (200g) was used as the starting material. The procedure of Wood ${ }^{7}$ was used to extract linamarase with the modification of 
using $5 \mathrm{mg}$ EDTA. $100 \mathrm{ml}^{-1}, 0.1 \mathrm{M}$ acetate buffer, $\mathrm{pH} 5.0$ for extraction. The rest of the procedure including $70 \%$ acetone precipitation and dialysis of the dissolved protein precipitate followed that described previously. ${ }^{7,8}$

(b) Determination of activity in leaf

Cassava leaf ( $9 \mathrm{~g}$ ) was pounded using a mortar and pestle and immediately extracted with $0.1 \mathrm{M}$ acetate buffer $\mathrm{pH} 5.0$ (10 $\mathrm{ml}$ containing $5 \mathrm{mg}$. EDTA 100 $\mathrm{ml}^{-1}$ buffer). The homogenate was dialysed for $24 \mathrm{~h}$ and centrifuged at 3000 $\mathrm{rpm}$ in a bench top centrifuge. The pellet was washed twice with buffer $(20 \mathrm{ml}$ each) and the total supernatant was made up to $50 \mathrm{ml}$ using the same buffer. This was analysed immediately by the syringe assay (see below).

Estimation of cyanide in leaf preparations:

(a) Free cyanide - The products of cooking were distilled (water distilled) into $6.25 \% \mathrm{Na}_{2} \mathrm{CO}_{3}(25 \mathrm{ml})$ and tested for cyanide by the picrate method.,8

(b) Bound cyanide - The product of free cyanide distillation was incubated with excess linamarase for $24 \mathrm{~h}$. then distilled and estimated as above.

In both cases a standard curve $\left(\mathrm{r}^{2}=0.9992\right)$ of $\mathrm{CN}^{-}$vs absorbance $(\mathrm{nm})$ was used.

Estimation of Linamarase activity of leaf: Linamarin was purchased from Sigma-Aldrich (USA). Linamarin (25 mg, i.e. approximately $\mathrm{Km}$ ) was dissolved in $1 \mathrm{ml}$ of water. This was added into a reaction mixture containing leaf linamarase extract $(0.2 \mathrm{ml})$ and buffer $(3.8 \mathrm{ml}$ of $0.1 \mathrm{M}$ acetate, $\mathrm{pH} 5.0)$. The reaction vessel was a graduated syringe $(5 \mathrm{ml})$ closed at its tip with a rubber bung. ${ }^{9}$ At zero time and 5 minute intervals aliquots of $1.0 \mathrm{ml}$ or $0.5 \mathrm{ml}$ were withdrawn and injected into $0.8 \%$ $\mathrm{Na}_{2} \mathrm{CO}_{3}(1 \mathrm{ml})$, saturated picric acid $(1 \mathrm{ml})$ and made up to $5 \mathrm{ml}$. The reaction mixture was then heated in a boiling water bath for $10 \mathrm{~min}^{7}$ and absorbance was measured at $530 \mathrm{~nm}$. The cyanide released was calculated using a standard curve containing molar equivalent amounts of glucose and $\mathrm{CN}^{-}\left(\mathrm{r}^{2}=0.9972\right)$. The time course was linear and activity of linamarase was calculated.

Estimation of Protein: Protein of cassava leaf (fresh and treated) was estimated by the Kjeldhal method ${ }^{10}$ in duplicate. The conversion factor was 6.25.

\section{RESULTS}

\section{Basic analytical data}

The protein content of fresh cassava leaf was found to be $28 \%$ dry weight. Moisture content was $89-90 \%$. Total cyanide (bound in free leaf) was in the range of $850-950$ $\mathrm{mg} \mathrm{kg}^{-1}$ fresh weight. 


\section{Traditional cooking}

Preparation of "malluma" and fried manioc led to decreased total cyanide but free cyanide content was well over the limits held permissible (3-5 ppm daily)., ${ }^{2,3}$ (Table 1).

\section{Detoxification processes}

Pounding in a mortar and allowing to stand for $2 \mathrm{~h}$ and cooking with coconut scrapings (1:1) led to a reduction of total and free cyanide content to $<0.5 \mathrm{mg} \mathrm{kg}^{-1}$ fresh weight of cassava leaf (Table 1).

The experiment shows that pounding and allowing to stand for $2 \mathrm{~h}$ activated a very active linamarase.

Table 1: Free and bound cyanide content in fresh and processed Cassava leaf.

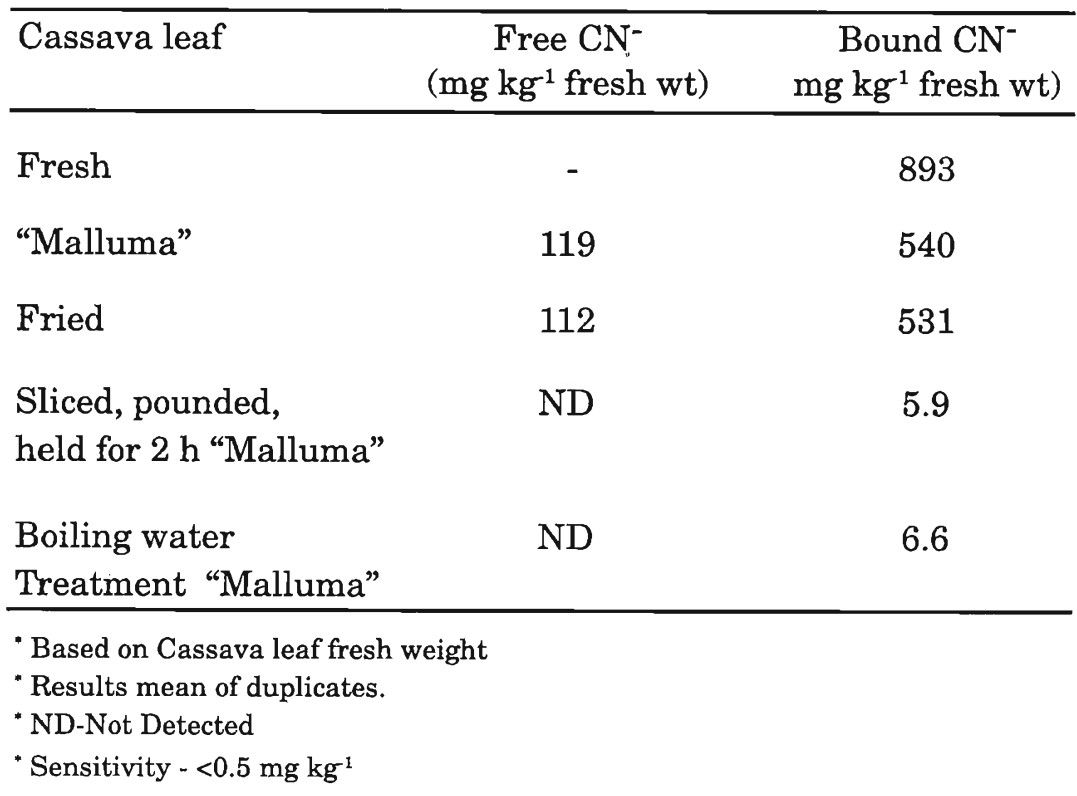

\section{Boiling Water treatment}

A similar lowering was observed on boiling water treatment (Table1). This detoxification does not affect protein level, which is still $28 \%$ of dry weight.

\section{Time Course}

On keeping pounded cassava leaf for $2 \mathrm{~h}$ at ambient temperature there was a rapid decline in cyanide content, reflecting high linamarase activity even at zero time 
after pounding. Table 2 summarizes the changes in cyanide content that occurs with time.

Table 2: Changes with time, of cyanide content in pounded Cassava leaves maintained at ambient temperature.

\begin{tabular}{ccc}
\hline \multirow{2}{*}{ Time $(\mathrm{h})$} & \multicolumn{2}{c}{ Total cyanide $\left(\mathrm{mg} \mathrm{kg}^{-1}\right)$} \\
\cline { 2 - 3 } & Dry wt & Fresh wt \\
\hline 0 & 84 & 9.7 \\
1.0 & 75 & 8.3 \\
2.0 & 66 & 7.3 \\
\hline
\end{tabular}

- Results based on duplicates

\section{Activity of cassava linamarase}

Cassava leaf linamarase activity was very high and amounted to $>1 \mathrm{mg} \mathrm{CN}^{-1} \mathrm{~g}$ dry $\mathrm{wt}^{-1} \mathrm{~min}^{-1}$. This provided credence to our hypotheses.

\section{Protein content}

Apparent protein content which was determined by Kjeldhal $\mathrm{N}$ was unaffected by treatment despite the loss of $\mathrm{CN}^{-}$, as nitrogen content (\% dry weight) is not affected, due to acetone which is not nitrogenous also being lost (Table 3 ).

Table 3: Protein content of fresh and processed Cassava leaves

\begin{tabular}{lc}
\hline Cassava leaf & Protein content (\% dry weight) \\
\hline Fresh & 28.1 \\
Boiling wash treatment & 28.0 \\
\hline
\end{tabular}

Mean protein values are those of leaves that are normally used for consumption. Loss of dry weight occurs due to both HCN $(\mathrm{N}=14, \mathrm{MW}$ of $\mathrm{HCN}=27)$ and acetone $(\mathrm{MW}=58)$. This accounts for constant $\mathrm{N}$ content as estimated by Kjeldhal on dry weight. Results are a mean of duplicates. 


\section{DISCUSSION}

It is clear that cooking of cassava leaf in the traditional method gives not only residual high bound cyanide but also unacceptable levels of free cyanide $\left(110-120 \mathrm{mg} \mathrm{kg}^{-1}\right.$ fresh weight), which can lead to chronic cassava toxicity ${ }^{2}$ in general, including goitre.$^{3}$ On field evidence, this is clearly the cause for high prevalence of goitre in the arid areas of Monaragala, Sri Lanka. There is cause to believe that chronic toxicity effects, such as ataxic neuropathy, vitamin $\mathrm{B}_{12}$ deficiency disorders ${ }^{2}$, cretinism $^{3}$, etc., which are less obviously seen than goitre could also be present due to the intake of these levels of cyanide. ${ }^{11,12}$ This is especially true as the nutritional status of the population is poor. Thus goitre may be the "tip of the iceberg" as far as chronic toxicity is concerned.

However it is clear that due to poverty of the people, simplistic advice such as not eating cassava leaf is not an option. This is particularly important, as the protein content of the leaves that are being used for consumption is around $28 \%$.

The processes of cooking advocated here can detoxify cassava leaf while not affecting its protein content. The methods are simple and easily adaptable.

Addition of limited amounts of boiling water before cooking is worthy of further consideration. For this technique to work, the cassava leaf linamarase must be so active that some of it survives denaturation for a finite though short time in order to hydrolyse all the linamarin.

An interesting observation is that pouring boiling water on cassava leaf in a cotton wool stoppered vessel does not yield positive result with picrate paper. (Dr. L.R. Vilvarajah, 2002 private communication). However if the resulting solution is mildly heated, cyanide is then liberated.

This can be explained with the knowledge that liberation of cyanide is a two step process. ${ }^{8,9}$
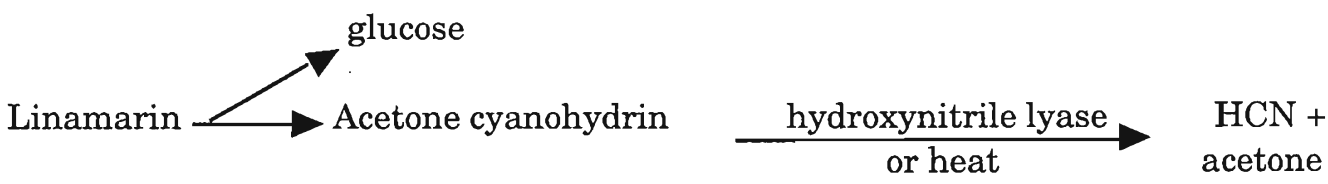

Clearly what is happening is that while the boiling water step allows linamarin to form the cyanohydrin, the treatment destroys hydroxynitrile lyase and therefore cyanide is not produced until the medium is heated. 
However, this is only of academic interest as both (i) the cooking processes advocated and (ii) the assays for cyanide, involve heating. The alkali medium of the assay also provides conditions for acetone cyanohydrin decomposition.

\section{Acknowledgement}

The authors thank Ms. S Jayasinghe of the Industrial Technology Institute (ITI) for Kjeldhal analysis, Dr. Pubudu de Silva for networking the project, Dr.M.R. Chandrasiri, District Medical Officer of the Sirigala Hospital, Dr D.P. Attapattu for his initial observations linking cassava leaf consumption with goitre and IPICS, Uppsala, Sweden, for financial assistance.

\section{References}

1 Centro Internationale Agricultur Tropicale (1979). Cassava program Annual report. Cali, Columbia pp 589.

2 Nestel B. \& Mackintyre R. (1973). Chronic cassava toxicity, Proceedings of an International Workshop Lond, 29-30 January, International Development Research Centre oloe pp 11-162.

3 Ermans A.M., Mbulanko N.M., Delange F. \& Ahawalia R. (1980). Role of cassava in the etiology of endemic goitre and cretinism. International Development Research Centre 1360e pp13 - 160.

4 Priyadharshani A.M.B. (2002). Detoxification of Manioc leaf. BSc(Hons.) Dissertation, Faculty of Medicine, University of Sri Jayewardenepura.

5 AOAC (1984). Official methods of analysis. 14 ${ }^{\text {th }}$ Edition (Ed. S. Williams) Washington D.C, 1984 7:004.

6 AOAC (1984). Official method of analysis. $14^{\text {th }}$ Edition (Ed. S. Williams) Washington D.C 1984, 14:062.

7 Wood T. (1966). The isolation, properties and enzymatic breakdown of linamarin from cassava. Journal of Science of Food and Agriculture 17: 85-90.

8 Pieris N. M., Jansz E.R. \& Kandage R.L. (1974). Cyanide content of Manioc An enzymatic method of determination applied to processed manioc. Journal of the National Science Council of Sri Lanka 2 : 67-76.

9 Pieris N.M. (1976). Studies of the cyanogenic glucosides and glucosidases of Manihot esculenta Crantz. PhD Thesis, University of Colombo. 
10 AOAC (1984). Official methods of analyses. $14^{\text {th }}$ Edition (Ed. S. Williams) Washington D.C. 1984, 14 : 067.

11 Delange F. \& Ahluwalia R. (1982). Cassava toxicity and thyroid - Research and public health issues, Proceedings of a workshop. Ottawa, Canada, 31 May2 June 1982, International Development Research Centre 207e pp 1-141.

12 Delange F., Iteke F.B. \& Ermans A.M. (1982). Nutritional Factors involved in the goitrogenic action of cassava. International Development Research Centre Ottawa, Ontario. pp11-90. 